\section{CLIMATE AND HUMAN COMFORT*}

\section{By PROF. DAVID BRUNT, F.R.S.}

Imperial College of Science and Technology, London

\section{Bodily Reactions to Heat and Cold}

$\mathrm{T}$ HE temperature of the deep tissues of the human body is said to be $98.4^{\circ} \mathrm{F}$. in normal conditions, any large deviation from this value being uncomfortable, and in extreme cases fatal. It is generally stated that a rise of body temperature to $107^{\circ} \mathrm{F}$. is likely to be fatal, but there is no equally definite range of fall of temperature which can be regarded as fatal. Heat is continually being generated within the body, even during sleep, as the result of the chemical processes associated with breathing, digestion and physical effort, all these processes being grouped under the term metabolism. This heat is conducted to the skin, partly by the normal conducting power of the body tissues, partly by the blood-stream, and is dissipated from the skin to the environment. Heat cannot be conducted to the skin unless the temperature of the skin is lower than that of the deeper tissues of the body. Observations show that the skin temperature varies over different parts of the body, being lowest of all over the feet, and next lowest over the hands. From this we may appreciate that special care is needed in the design of boots and gloves for men exposed to conditions of extreme cold.

When the body is exposed to cold, the following reactions occur: $(a)$ the skin temperature falls; (b) there is an onset of shivering, an involuntary effort to increase the internal production of heat by muscular action; and $(c)$ the adrenal and thyroid glands discharge fluids which accelerate the metabolic generation of heat.

When the body is exposed to heat, the sweat glands discharge sweat on to the surface of the skin, where it evaporates, and in so doing takes heat from the body. Heat is dissipated from the skin in three ways : (a) by radiation exchange between the outer surface, partly clothing, partly uncovered skin which the body presents to the environment; $(b)$ by convection of heat, which can be simply described as the carrying of heat from or to the surface of the body by the air coming into contact with it; and $(c)$ by the evaporation of sweat.

There is in addition a small loss of heat in the respiratory passages and lungs; but in the discussion of the heat balance of the body we may neglect this item, though it may well be an important factor in determining comfort.

Indoors, the three items mentioned must balance the metabolic rate of generation of heat. Out of doors, in bright sunshine, the gain of heat from the sunshine is effectively an addition to the metabolic rate. The convective loss or gain is proportional to the square root of the air speed, and the evaporation from unit wetted area of the skin, in given conditions of air temperature and humidity, must also depend on air speed in the same manner.

In low and moderate air temperatures, the evaporative loss of heat from the skin is practically independent of air temperature, and the only controllable modes of dissipation of body heat are those due to radiation and convection. These two factors are proportional to the difference between the temperatures of the surface of the body and of the air,

- Discourse delivered at the Royal Institution on March 9. while the convective loss is also proportional to the square root of the air speed. Further, an increase in the amount of clothing worn has the same effect as putting an additional resistance into an electric circuit. It decreases the outward flow of heat and raises the skin temperature. The rate of loss of heat from the body can thus be decreased by wearing more clothing, by increasing the air temperature, or by decreasing the air movement; and it can be increased by reversing one or all of these possibilities.

In high temperatures, or during great physical exertion, the secretion of sweat and its evaporation is the main factor in the dissipation of heat from the skin. An examination of the measured rates of loss of heat by convection and evaporation shows the curious result that, even when the body appears to be completely wetted with sweat, the area of skin from which evaporation occurs is only about one third of the area from which heat is lost by convection. The rate of evaporation from unit wetted area is the greater the higher the wind speed, and the lower the humidity of the air. If, while the temperature is kept constant at such a high level that active sweating occurs, either the humidity is increased, or the air speed decreased, or both changes are made, the body responds by an increase of the wetted area of skin. The reverse of this statement is also true. No instrument can produce a parallel to this response, and so it is not to be expected that any instrument will enable us to measure in a simple manner the reaction of the human body to given atmospheric conditions.

We find that the human body can so react to a wide range of external conditions as to preserve the internal temperature at $98 \cdot 4^{\circ} \mathrm{F}$. or near it. The skin tries to produce its own climate. This effort is most successful when one is just comfortably warm in bed, the temperature under the bedclothes being then $85^{\circ}-86^{\circ} \mathrm{F}$.

\section{Limits of Heat-stroke Conditions}

A long series of measurements of the various factors involved in the heat balance of the body in controlled conditions of temperature, humidity and ventilation, made in the John B. Pierce Laboratory of Hygiene, Newhaven, Conn., by the Director (Dr. C. E.-A. Winslow) and Drs. Herrington and Gagge, enable us to write down expressions for the magnitude of the heat losses from the body in any given conditions. The equation of heat balance of the body can be written in such a form as to give the highest relative humidity in which body temperature can remain constant, in given conditions of air temperature and ventilation. To allow for the possibility of very light ventilation, this is taken to be $17 \mathrm{ft}$. per minute, and in what follows this rate of ventilation must be regarded as assumed, unless some other rate is specifically mentioned. It is also assumed that the temperature of the radiating solid surfaces in the environment is equal to the air temperature.

The details of the computation have been given elsewhere, and will not be repeated here. Fig. I shows the results of five such computations. For men resting indoors, or in the shade, Curve $A A$ gives the limit of tolerable conditions for a nude man, and Curve $B B$ for a lightly clothed man. In conditions represented by a point to the left of the appropriate curve for nude or clothed men, the body temperature will not rise, while in conditions represented by any point to the right of the curve the body tomperature will rise, and will continue to rise so long as exposure 


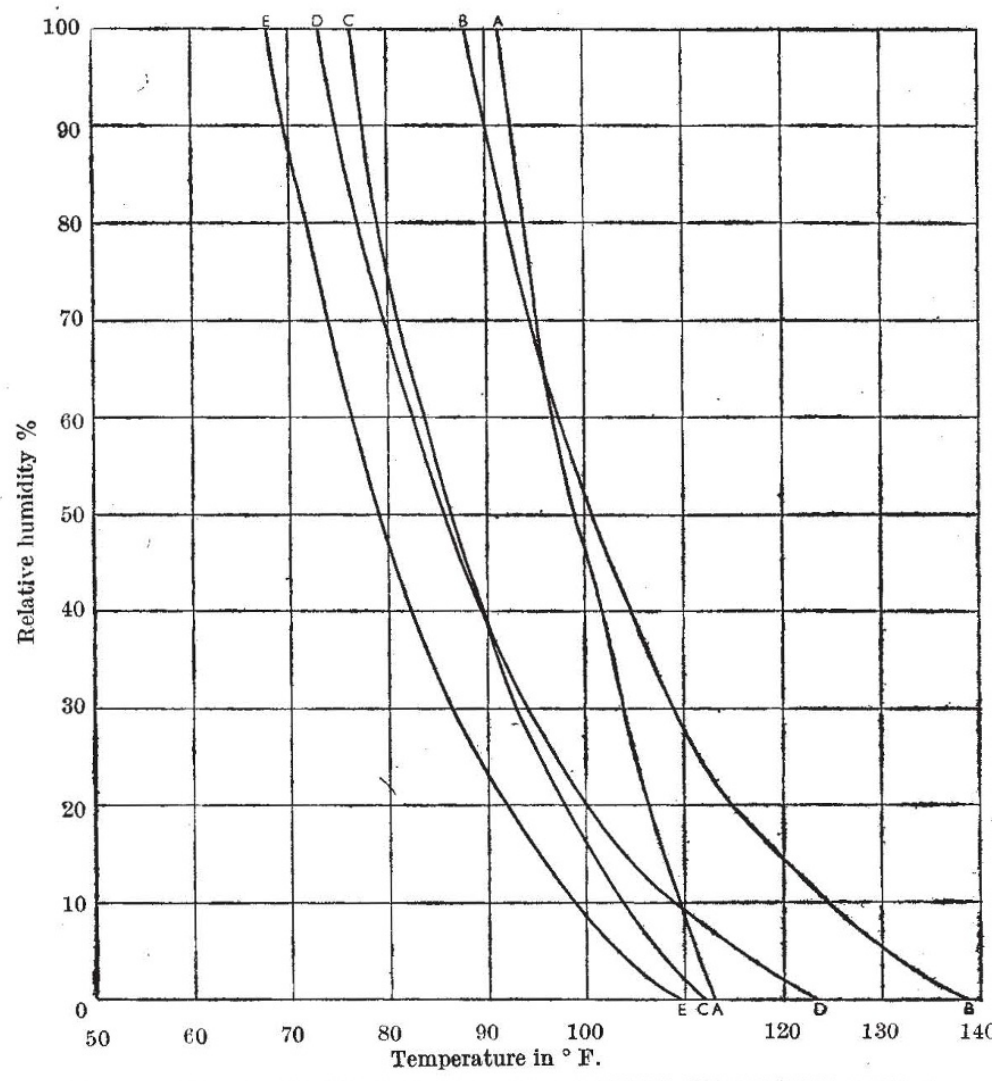

Fig. 1*. CURVES SHOWING THE LIMITS OF THE RANGE OF TOLERABLE CONDITIONS FOR VARYING DEGREES OF ACTIVITY ; $A A$. FOR NUDE SUBJEOTS RESTING INDOORS ; FB FOR CLOTHED SUBJECTS RESTING INDOORS ; $C C$ FOR CLOTHED SUBJECTS RESTING BN SUTSHINE; $D D$ FOR CLOTHED SUBJECTS WATKINA AT 4 M.P.H. (NO SUNSHINE); $E E$ FOR CLOTHED SUBJECTS WALKING AT 4 M.P.H. IN BRIGHT SUNSHINE.

* Figs. 1, 2 and 3 are from Prof. Brunt's paper in Endeavour of July 1944

A ready check on the limits set by Curve $B B$ in saturated air is fortunately available. It has been pointed out by the late Dr. J. S. Haldane that in saturated air in coal mines, a temperature of $88^{\circ} \mathrm{F}$. is about the highest temperature which can be tolerated, even by men not doing any work. This close agreement affords some confirmation of the reliability of the computations on which Fig. 1 is based. Exposure to conditionsin which body temperature rises by $1-11_{2}^{\circ} \mathrm{F}$. per hour produces no permanent injury, provided the exposure is not continuous over a long period. Thus, with periodic withdrawal to cooler conditions, miners can work in conditions in which long-continued exposure would end in heat-stroke.

\section{Acclimatization}

It is generally acknowledged that, within limits, it is possible for a man to accustom himself to living and working in temperatures above or below the normally accepted limits. Acclimatization to hot conditions consists largely in training the sweat glands to function efficiently, and perhaps in part in learning to avoid strenuous exertion. In temperate climates some degree of acclimatiza. tion is necessary at the beginning of each summer, since the sweat glands are inactive during the winter. When a very hot day comes at the beginning of summer, it is far more distressing than an equally hot day later in the summer.

to these conditions is continued. With continued rise of body temperature, the blood-pressure falls, the pulse-rate increases, strong palpitation occurs, followed by a condition of stupor, ending in death by heat-stroke. It is seen in Fig. 1 that the wearing of clothing affords considerable protection against heat, since, in completely dry air, the upper limit of tolerable temperature is about $138^{\circ} \mathrm{F}$. for a clothed man, and $113^{\circ} \mathrm{F}$. for a nude man.

Nothing that has been written above should be regarded as excluding the possibility of remaining for short periods in air at temperatures far beyond the limits prescribed by Curves $A A$ and $B B$ of Fig. 1. In the Philosophical Transactions of the Royal Society of 1775 will be found several papers by Dr. Charles Blagden, later secretary of the Royal Society, in which are described experiments in rooms kept at very high temperatures. Blagden stayed in a room, in which the air temperature was maintained at $240^{\circ}-260^{\circ} \mathrm{F}$., for a period of eight minutes ; during the first seven minutes he experienced no discomfort, but the subsequent rapid increase of distress in breathing and of a feeling of anxiety caused him to leave the room after a total stay of eight minutes.

In Fig. 1 Curve $C C$ represents limiting conditions for a lightly clothed man, sitting in bright sunshine, Curve $E E$ the limits for a clothed man walking at 4 m.p.h. in bright sunshine, and Curve $D D$ the limits for a clothed man walking at 4 m.p.h. on a cloudy day.
Men who work in the very hot deep mines of South Africa are subjected to a regular process of acclimatization, first doing very light work in hot stopes, and increasing slowly their rate of work. But even after acclimatization, when working in the hotter mines coloured workers show a definite rise of internal tem perature, sometimes amounting to $2^{\circ} \mathrm{F}$. or mor when working in air, say, of temperature $85^{\circ} \mathrm{F}$. relative humidity 98 per cent (wet bulb temperatur $84 \cdot 6^{\circ} \mathrm{F}$.), and ventilation $20 \mathrm{ft}$. per minute. Ir saturated air there can be no loss of heat from the skin, either by convection or by evaporation 0 : sweat, unless the skin temperature is higher than the air temperature. Further, if heat is to be transportec to the skin from the deeper tissues, the internal tem perature must be higher than the skin temperature So, when a man works in saturated air at $95^{\circ} \mathrm{F}$., his skin temperature must be higher than $95^{\circ} \mathrm{F}$., anc his internal temperature must be several degrees abovt the normal value, probably $101^{\circ}-102^{\circ} \mathrm{F}$. at lowest.

\section{Effect of Increased Ventilation}

It is easy to compute limits of tolerable condition with any selected rate of air motion, for nude sub jects. The extension of the preceding work fo clothed subjects is not at the moment possible. Th conductivity of the clothing with air speed $17 \mathrm{ft} . / \mathrm{min}$ has been evaluated from experimental data, bu there is not available any series of observations fron which the conductivity of clothing can be related $t$ the air speed. 


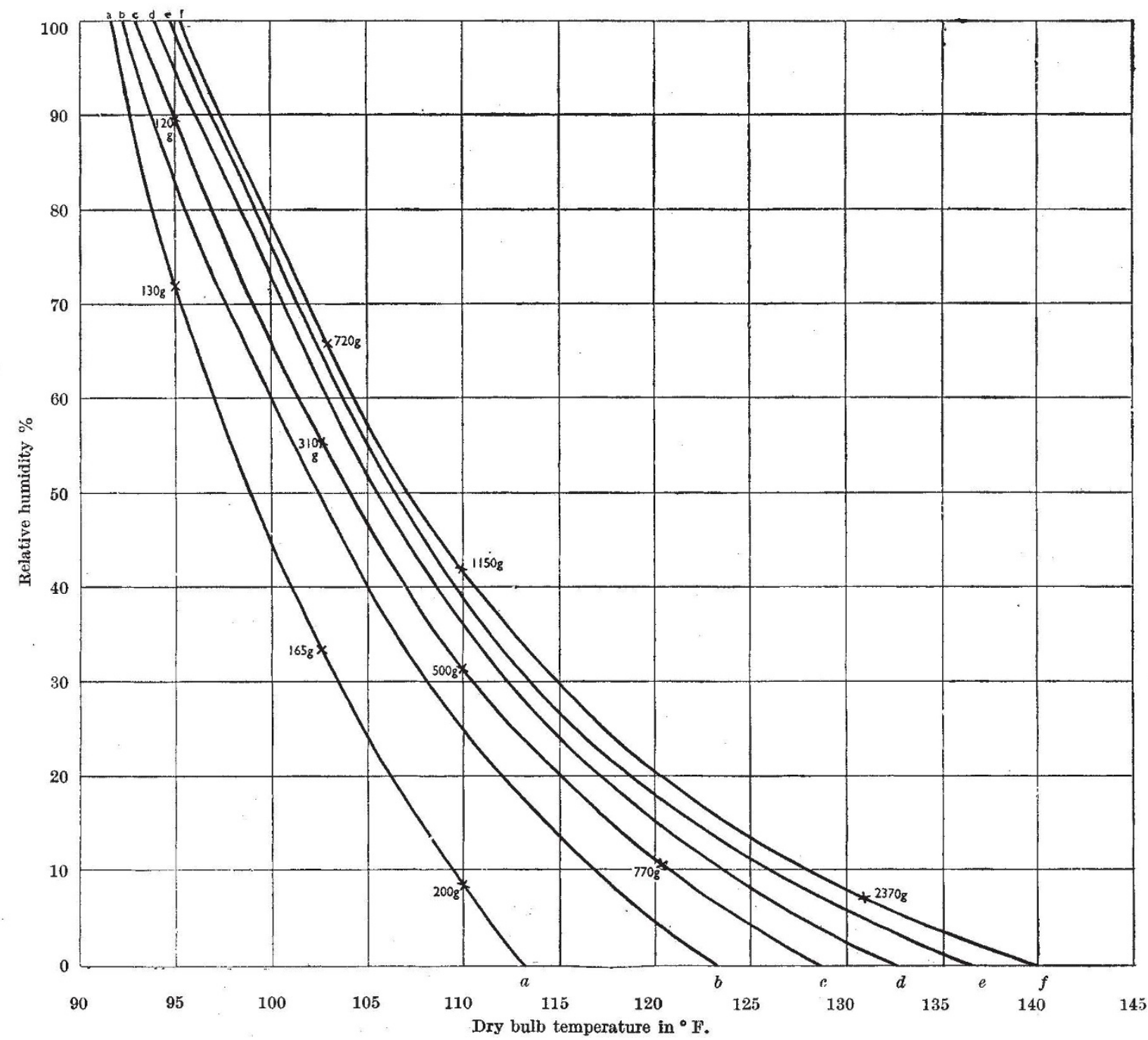

Fig. 2. THE EFFECT OF VENTILATION ON HEAT-STROKE CONDITIONS FOR NUDE SUBJECTS. THE CURVES GIVE IIMITINA TOLERABLE CONDITIONS, a a FOR AIR MOVKMENT 0.085 METRE PER SECOND (17 FT. PER MINUTE); $b b$ FOR 0.25 METRE PER SECOND (50 FT. PER MINUTE); $c c$ FOR 0.5 METRE PER SECOND (100 FT. PER MINUTE); $d d$ FOR 1 METRE PER SECOND (200 FT. PER MINUTE); $e$ FOR 2 MEIRES PER SECOND (400 FT. PER MINUTE); $f f$ FOR 5 METRES PER SECOND (1,000 FT. PER MINUTE). FIGURES SUCH AS $200 \mathrm{~g}$. MARKED ON THE CURVES INDICATE THE RATE OF LOSS OF WATER PER HOUR BY EVAPORATION FROM THE WHOLE BODY, SKIN AREA BEING ASSUMED TO BE 1.8 SQUARR METRES.

Fig. 2 reproduces a series of curves for six values of the air speed. It is seen that in a wind of a little more than 2 m.p.h. the limits are given by $d d$, and with relative humidity 60 per cent, the tolerable temperature is about $6^{\circ} \mathrm{F}$. higher than with air speed $17 \mathrm{ft} . / \mathrm{min}$. , while in completely dry air the corresponding rise in tolerable temperature is nearly $20^{\circ} \mathrm{F}$. The numbers shown on the curves indicate the rate of loss of water from the skin by evaporation of sweat, from the whole body of a man of average size. (Skin area $1.8 \mathrm{sq}$. metres, or 19.4 sq. ft.) For example, the $130 \mathrm{~g}$. indicated on Curve $a a$ at $95^{\circ} \mathrm{F}$., relative humidity 72 por cent, indicates that a man resting indoors in such conditions would lose water from the body by sweat at least at the rate of one pint in a little more than four hours. The 1,150 g. shown at temperature $110^{\circ} \mathrm{F}$., relative humidity 42 per cent, indicates that a man resting in the shade in these conditions with a wind of $1,000 \mathrm{ft} . / \mathrm{min}$. (11.1 m.p.h.) would lose water by sweating at the rate of at least two pints per hour, while the figure of $2,370 \mathrm{~g}$. lower on the Curve $f f$ indicates a loss of more than half a gallon per hour.

There are two aspects of these high rates of sweating which deserve further consideration. In the first place, sweat is not pure water, but contains, in addition to various organic compounds, common salt, and the salt lost by sweating must be replaced, or serious consequences to health will follow. Of these consequences miner's cramp is frequently cited as a typical example. In the second place, it should be noted that it is possible for dehydration of the body to cause sweating to stop. The consequences may be fatal. If, for example, a man is exposed to a wind of just over 11 m.p.h., at a temperature of $110^{\circ} \mathrm{F}$. and relative humidity 42 per cent, his body temperature can remain normal so long as he sweats at the rate of about two pints per hour. If he stops sweating, he will thus be exposed to conditions in which radiation and convection heat the body, while 
there is no evaporative loss of heat from the skin. His body temperature will then rise, and he will die of heat-stroke. This appears to be the explanation of the deaths from the Simoom, the hot dry Poison Wind of Arabia, in which whole parties of men have perished together.

In very hot air of any assigned temperature and humidity, for any assigned rate of sweating there is a limiting air speed at which sweat is evaporated as rapidly as it is secreted. An increase of air speed beyond this limit, when a man is already sweating at his highest possible rate, will not increase the evaporating cooling, but will increase the convective heating, of the body. The body temperature will then rise, and will go on rising so long as the high air speed is maintained. This effect is to be observed in hot mines, where there may be a limit to the air speed in which efficient work is possible.

\section{Classification of Climates}

In Fig. 3 are collected together such information as can be applied to classify climates. We have to allow for the possibility of very light winds. Lines $B B, C C$ and $E^{\prime} E$ are copied from Fig. 1. To the right of $B B$ conditions are intolerable for long-continued exposure. Between $B B$ and $C C$ a man cannot rest in bright sunshine without rise of body temperature or risk of heat-stroke, and cannot make any physical effort without such risk. This area in the diagram is marked 'very hot'. In conditions represented by the area between $C C$ and $E E$ a man cannot walk at 4 m.p.h. in bright sunshine without rise of body temperature, and the corresponding area in the diagram is marked 'warm'. At the other end of the temperature scale, it is generally agreed that at temperatures below $50^{\circ} \mathrm{F}$. it is cold, and at temperatures between $50^{\circ}$ and $60^{\circ} \mathrm{F}$. it is cool. We are therefore left with an area bounded by the $60^{\circ} \mathrm{F}$. vertical line and the curve $E E$, which will contain the zone of possible pleasant conditions.

Within this range of conditions, by wearing suitable clothing, it is possible to do light work indoors or in the shade without sweating, and to rest without shivering. Experience in air-conditioning has confirmed this, and has shown that, with medium relative humidity, men can do light work indoors with the maximum degree of comfort in temperatures between $60^{\circ}$ and $76^{\circ} \mathrm{F}$. The optimum temperatures prescribed by heating and ventilating engineers are, in the United States, $76^{\circ} \mathrm{F}$. in summer, $72^{\circ}$ in winter ; in England, $66^{\circ}$ in summer, $62^{\circ}-64^{\circ}$ in winter.

Very high relative humidity is oppressive at high and moderate temperatures, and raw at low temperatures. Very dry air is keen at low temperatures, while at moderate and high temperatures it is at first stimulating, but ends by producing irritation, headaches, and a marked tendency to becoming quarrelsome. The Föhn wind, a warm dry wind which blows down the sides of many mountain ranges, has long been notorious for producing these effects of irritability and quarrelsomeness, and dwellers in some desert regions manifest an undesirable permanence of irritability.

Fig. 3 is based on an assumption which was stated earlier, but requires emphasizing, that the temperature of solid surfaces is the same as the air temperature. There are conditions in which this assumption is not justified, particularly in hot sunny climates, in which the walls and roofs of houses and any solid objects exposed to the sunshine attain $a$ very high temperature. When this occurs, the radiation from the solid surfaces in the environment will be much greater than would be computed on the basis that they are at air temperature. Contact with very hot solid objects leads to a degree of discomfort which can only be described as little short of misery. Most white men find that a temperature of $105^{\circ} \mathrm{F}$. is near the limit of tolerability in these conditions.

It follows that there are two types of hot climates : (a) the oppressive, warm, damp type of climate, usually with overcast skies and little fall of temperature at night; and $(b)$ the hot dry sunny climate, the undesirable nature of which has been stressed in the last paragraph. Comfort is determined by the temperature, humidity and rate of motion of the air. If air-conditioning were possible, we should treat $(a)$ by drying, and $(b)$ by cooling, the air indoors. In the absence of air-conditioning, all that can be done in case $(a)$ is to increase the ventilation, or to sit in the greatest draught. In case $(b)$ increase of ventila. tion is not effective, and it is better to close all doors and windows of the house in the early morning while the air is still cool, and to ventilate indoors by electric fan where possible. The oppressive warm, damp climate calls for an open type of house permitting free air movement, while the hot, dry, sunny climate calls for a house having double walls and roof, with a wide air space, and capable of being closed up fairly tightly against the intrusion of the hot outer air during the day.

In India, a simple expedient is frequently adopted for cooling the air in houses, water-soaked curtains or tatties being hung over doorways through which air enters the rooms. The evaporation of water from the tatties into the air cools the air, by taking from it the latent heat required for evaporation. Now in such a process of evaporation, while the dry-bulb temperature falls, the wet-bulb temperature of the air remains constant. But it would be found that along any of the curves of Figs. 1 and 3, the wetbulb temperature falls as the temperature rises. In other words, a given wet-bulb temperature becomes more uncomfortable, for any degree of physical effort, in any degree of ventilation, as the dry-bulb tem. perature increases.

\section{The Ideal Climate}

Can we now determine the ideal climate? To this question a definite answer can be given provided we have a clear statement of the idea underlying the search for the ideal; and we must avoid the common error of regarding the climate in which it is pleasant to spend a summer holiday as the ideal climate in which to live permanently, and to do one's work. Before we can determine the ideal climate we must, in fact, know for what degree of activity the climate must be ideal. Clearly the ideal will not be found either in the very cold polar regions or the very hot tropical regions. In a paper published some two years ago, I endeavoured. to solve the first stage of the problem by postulating that it should be possible for a lightly clothed man to walk at four miles per hour in the sunshine without sweating, and to sit in the sunshine, or stand or sit in the shade or indoors doing light work, without shivering. With relative humidity of about 60 per cent, the temperature to fit this prescription will be between $66^{\circ}$ and $68^{\circ} \mathrm{F}$., and the optimum is thus $67^{\circ} \mathrm{F}$. For the nude man the optimum temperature will be about $4^{\circ}$ higher, say $70^{\circ}-71^{\circ} \mathrm{F}$. 




Fig. . TENTATIVE OLASSIFICATION OF CLIMATES.

Major S. F. Markham, in his book "Climate and the Energy of Nations", has directed attention to the fact that, on a world map of annual mean temperatures, the $70^{\circ}$ isotherm passes through, or close to, all the centres of early civilizations in Egypt, Palestine, Assyria, Sumeria and Persia, and not far north of Mohenjodaro, the centre of the early civilization in the velley of the Indus. Thus the early civilizations arose in regions where the mean tem. perature of the year is now, and probably was then, $70^{\circ} \mathrm{F}$. or very near it; and as they were founded by men who wore so little clothing that we may regard them as nude, we may take this as a confirmation of the estimate given above of the ideal temperature for the nude man.

An annual mean temperature of $70^{\circ} \mathrm{F}$. would mean a summer temperature well above the limit, and a winter temperature well below it, so that the summer afternoons would be too hot, and the winter nights too cool, for comfort. With the development of methods of indoor heating in winter, the optimum conditions would shift to climates where the summer heat was less extreme; but the winter cold not such as to make indoor heating impossible, as exemplified in ancient Greece, and still more notably in the Roman Empire. With the fall of the Roman Empire, indoor heating became far less common, and almost died out, and the next major eivilization, the Muslim, was again in the region of the $70^{\circ} \mathrm{F}$. isotherm. Later on, in western Europe, as indoor heating developed, and houses once again became weather-proof, civilization began to make rapid strides.

We can now go a stage further, and state that for a healthy and active life the climate must be such that the mean temperature of the hottest month shall not exceed $70^{\circ} \mathrm{F}$., or at most $75^{\circ} \mathrm{F}$., while the coldest month of the year shall not be so cold that it becomes difficult or expensive to maintain a comfortable temperature indoors. Markham (loc. cit.) states that when a white man migrates to a country where the mean temperature of the hottest month of the year exceeds $75^{\circ} \mathrm{F}$. he finds that, whereas he and his children may be able to tolerate the changed conditions, his grandchildren will show a marked loss of energy and of mental and physical efficiency. Markham suggests that the 'poor white' problem which has arisen in many hot countries is a result of migration to unsuitable climatic conditions. It is unlikely that any simple hard-and-fast rule can afford a solution of the problem of desirable climates. Some allowance must be made for the effects of low relative humidity and of high wind speed, in modifying the disabilities of hot climates.

An examination of world maps of mean temperatures for each month of the year shows that only a very small fraction of the land areas satisfies the condition that the hottest month of the year has a mean temperature not above $75^{\circ} \mathrm{F}$., while the coldest month of the year has a mean temperature not below freezing point. The largest single area satisfying these conditions is that part of western Europe which includes the British Isles, France, northern Spain, Switzerland, Germany, the Netherlands, Denmark, and a strip along the south-western shores of Scandinavia. Within this area, there is a higher level of health and prosperity than in the neighbouring regions.

Markham quotes a considerable volume of statistics 
relating to health and prosperity for different countries, showing the lowest death-rate and the lowest infantile mortality for the years 1926-35 to be those of New Zealand, the country which I have always regarded as having the best climate of all countries in the world. Over most of New Zealand the mean temperature of the hottest month lies between $62^{\circ}$ and $70^{\circ} \mathrm{F}$., and that of the coldest month between $45^{\circ}$ and $52^{\circ} \mathrm{F}$. We might compare these figures with the corresponding figures for the British Isles, where the July mean temperature lies between $58^{\circ}$ and $62^{\circ} \mathrm{F}$., while the mean temperatures of the coldest month of the year lie between $39^{\circ}$ and $44^{\circ} \mathrm{F}$. In the British Isles, temperature readings above $90^{\circ} \mathrm{F}$. are infrequent, and values exceeding $95^{\circ} \mathrm{F}$. are decidedly rare, being generally confined to the inland regions of the southern half of England. In the British Isles the highest temperature recorded during a month may exceed the mean for that month by about $20^{\circ} \mathrm{F}$. in winter, and by about $30^{\circ} \mathrm{F}$. in summer, while the lowest temperature recorded may fall below the mean of the month by about $30^{\circ} \mathrm{F}$. in winter, and by about $20^{\circ} \mathrm{F}$. in summer.

\section{Development of the Weather-proof House in England}

The weather-proof house required glass for the windows, bricks for parts at least of the structure, and the fireplace and chimney as we know it. The history of the development of these three features in England is by no means clear. Houses were glazed in the Roman Empire, but the making of glass disappeared from Britain with the Romans. The Venerable Bede described how, in 675 , Benedict, when building a church at the mouth of the Wear, had to go to France to find and bring back glass workers to glaze the windows of his church. Bede further states that these glaziers not only glazed the church windows, but also taught the English how to make glass. The knowledge they imparted was not lasting, for in 758 we find the Abbot of Jarrow appealing to the Bishop of Mainz to send him a craftsman in glass. The earliest evidence we find of glass-making in England refers to 1230, in which year a deed granted certain lands at Chiddingfold in Surrey to one Lawrence, "vitrarius". Chiddingfold was apparently the earliest centre of glass-making, but English glass was poor in quality until the sixteenth century. Even then glass windows were so rare and valuable that they were often bequeathed, like jewels, apart from the house. The decision by the Court of Common Pleas in 1599, that glass windows should not be removed from a house, reveals the prevailing state of things with regard to windows.

Aubrey, an antiquarian writer of the seventeenth century, said that glass windows were rare except in churches and gentlemen's houses until the time of Henry VIII, and added that to his own remembrance, copyholders and poor people in Herefordshire, Monmouthshire and Shropshire had none before the Civil War. Aubrey also wrote that before the Reformation, ordinary men's houses "had no chimneys, but flues like louvre holes. Some of 'em were in being when I was a boy".

So far as definite records are available, bricks were first made in England (at Hull) in 1303, and only became reasonably good and cheap a century later. One of the earliest examples of brickbuilding in England, with English bricks, is the north and east part of Queens' College, Cambridge, built in 1448 .

There are still to be seen in England a few houses with fireplaces and chimneys as we know them dating back to the middle of the twelfth century, as for example the Norman House at Christchurch, Hants (the ruins of which are in the gardens of the King's Head Hotel), built between 1125 and 1150, and a house at Boothby Pagnell, Lincoln, built about 1150 . But chimneys as we know them only became common about the time of Henry VIII.

We can thus say that by the time of Henry VIII the weather-proof house had beeome possible in England, but was still too expensive except for the wealthy, and that it was late in the sixteenth century before it became widespread throughout the country. The development on the Continent was roughly parallel with that in England. Once weather-proof houses had become general, England had a great advantage in its cheap supply of coal for indoor heating, and it may not be a fortuitous coincidence that the glories of Elizabethan England came soon after the advent of the weather-proof house.

\section{MICROBIOLOGY}

\section{ITS BASIC CONCEPT AND ITS FUTURE}

\author{
BY DR. A. C. THAYSEN \\ Director, Colonial Microbiological Research Institute,
Trinidad
}

$\mathrm{I}^{\mathrm{T}}$ will probably be conceded that the terms 'micro. biology' and 'biochemistry' can be roughly trans. lated into English as the knowledge of invisible life and as the chemistry of the living cell respectively. As such, these definitions aptly circumseribe the fields of study embraced by the two branches of science. Yet, all too often, the term microbiology is referred to as synonymous with that of biochemistry, as if these two branches of science dealt with identically the same problems, required the same training, and would use the same approach to the solution of their problems. This, however, is not necessarily the case and has no foundation in the basic concept of microbiology.

If one searches for this basic concept, one must eventually be led back to the living cell itself as it exists in its natural habitats. For only by a study of the changes which the cell performs under such conditions does it appear possible to obtain a correct insight into its functions; and only by an evaluation of these functions under controlled growth conditions can a measure be obtained of the future possibilities of the science of microbiology. This is undoubtedly the lesson to be learned from the polemic between Pasteur and Liebig in their writings on the function of yeast in fermentations, and it is the axiom insisted upon by Koch, when he demanded that, before a disease can be ascribed to the action of an organism, it is essential to grow the suspected type under artificial conditions free from all others and to produce with the cultured specimen the identical symptoms in healthy animals which had been observed to occur in diseased forms under natural conditions.

A primary function of microbiology then appears to be the study of micro-organisms in their natural habitats and to endeavour to isolate them from these for cultivation under artificial conditions with the view of reproducing natural changes or any other changes of which they may be found capable. 